ANNUAL REVIEW

\title{
Infectious diseases: Annual review of significant publications
}

\author{
Hobart A. REImanN \\ M.D. \\ The Hahnemann Medical College and Hospital, Philadelphia, U.S.A. 19102
}

\section{Introduction}

As in previous years, advances in knowledge of infections accrued, especially about viruses, the diseases they cause and protection against them, and in reactions of immunity in general. Hepatitis and herpes viruses claimed much attention, respiratory tract infections less than usual. The relation of EB and other viruses to cancer still is obscure. Venereal diseases continued to increase in incidence. New and expensive antimicrobial drugs were widely used, but few exceeded the value of older ones. Antimicrobialresistance increased apace. Many reports dealt with the dangers of iatrogenic and nosocomial infections.

\section{Viral infections}

\section{Hepatitis}

Hepatitis B, as an occupational hazard, involved ten hospital employees after exposure to a patient who had received many blood-transfusions. ${ }^{1}$ Four of five surgeons were infected during operation on a patient. Three had concurrent arthritis. ${ }^{2}$ More articles on the subject appeared in the July 23 Journal of the American Medical Association and in the July Archives of Internal Medicine. Hepatitis occurred in $30 \%$ of 200 drug addicts. ${ }^{3}$ According to two articles in the Lancet of June 30, sexual intercourse and domestic contact are likely sources of infection. Infection with hepatitis B virus seems to be as universal as that of cytomegalovirus or herpes virus. ${ }^{4}$

Among more than $2 \mathrm{~m}$ blood samples from volunteer donors, $0 \cdot 10 \%$ contained $\mathrm{HB} \mathrm{Ag}$. The ratio of subtype ad to ay was $5.8: 1$, and lower in the northern U.S.A. $\mathrm{Hb} \mathrm{Ag}$ was three times higher in paid blood donors than in volunteers. ${ }^{6}$ HB $\mathrm{Ag}$ appeared in $79.5 \%$ of patients at some time after exposure to infection. Fifty-six per cent of normal donors had subtype ad $\mathrm{HB} \mathrm{Ag}$ and $75 \%$ of patients with post-transfusion hepatitis had subtype ay suggesting that healthy carriers present little danger of transmitting infection. Subtypes may reflect epidemiological features, not biological differences of strains. ${ }^{7}$ Immunity often follows early exposure to the virus. ${ }^{8}$

Hepatitis probably is a systemic disease. Therapy failed in nine comatose patients. In one, most organs were damaged and $\mathrm{HB} \mathrm{Ag}$ was present in each. ${ }^{9}$ Injected heat-inactivated $B$ antigen may meliorate the disease ${ }^{10}$ and eventually a vaccine may be prepared. ${ }^{11}$ Radioimmunoassay detected twice as many infections with hepatitis B virus as other tests. ${ }^{12}$ Infection was induced experimentally in chimpanzees. ${ }^{13}$

Hepatitis A. Further evidence supports the identity of a virus recovered from marmosets inoculated with blood from patients with hepatitis $A$ to that of hepatitis A. ${ }^{14}$ Inoculation resulted in characteristic evidence of the infection. ${ }^{15}$ Convalescent serum from patients neutralized the infectivity of the agent in marmosets. ${ }^{16}$ Virus particles appeared in stools during the acute phase of disease. ${ }^{17}$

\section{Herpes hominis}

Except for pain and tenderness, herpes virus type 2 penile lesions may be mistaken for other chancres. Virus was present in $6 \%$ of urethral swabs, in one accompanied by $T$. pallidum. ${ }^{18}$ Type 1 virus caused intrauterine infection of an infant. Six instances have been observed resulting in congenital malformations, cerebral injury, mental retardation and other defects. ${ }^{19}$ Six adults had herpes hepatitis subsequent to infection elsewhere chiefly of the oral mucosa. Because of its bad prognosis, therapy with cytosine arabinoside or idoxuridine was recommended. ${ }^{20}$ Among twenty patients with herpes virus encephalitis treated with idoxuridine, thirteen showed apparent improvement, nine are well and two died. Of nine untreated patients, six survived but only one recovered completely. ${ }^{21}$ Herpes hominis virus, the commonest cause of sporadic necrotizing encephalitis, affected seven patients. Of four treated with 
idoxuridine, three died. In one instance, as much virus was in the brain after a full course as initially. Two treated with cytarabine have chronic disease. ${ }^{22}$

Labial lesions seemed to respond and recurrences were prevented by applying fluorescent light to lesions treated with neutral red dye. ${ }^{23}$ Therapeutic photoinactivation of herpes virus may be hazardous and lead to changes that result in oncogenesis. ${ }^{24}$ BCG vaccination apparently prevented recurrences of genital herpes type 2 infection incident to menses. ${ }^{25}$ Repeated application of ether or chloroform is recommended as the safest treatment for ethersensitive labial herpes. ${ }^{26}$ Controversy continues about the relation of herpes viruses to cancers. A latent virus may become active in dysplasic cells. ${ }^{27},{ }^{28}$ Patients with cervical carcinoma had antibody to type 2 herpes virus twice as often as in normal women. ${ }^{29} \mathrm{~A}$ recently published book ${ }^{30}$ and a review in the September 27, October 4 and 11 New England Journal of Medicine summarize knowledge about herpes and varicella-zoster viruses.

\section{Meningoencephalitis}

Besides measles and smallpox, vaccinia virus also may be a cause of subacute disseminated encephalomyelitis years after vaccination. ${ }^{31}$ Measles virus may be a cause of multiple sclerosis. ${ }^{32}$ As yet, no evidence of any viral infection has appeared in brain tissue from a patient. ${ }^{33}$ Measles antigen in infected neurons and glial cells may be involved in the cytolysis of sub-acute sclerosing panencephalitis. ${ }^{34}$ The increase in the incidence of SSPE in New Zealand may be related to vaccination against poliomyelitis. Either SV40 or measles virus may have been contaminants. ${ }^{35}$ Slow viruses were even considered as a cause of schizophrenia. ${ }^{36}$ Knowledge of conventional and unconventional slow viruses was summarized in Science of June 29 and July 6.

Powassan virus, present in rodents, caused nonfatal encephalitis in a resident of New Jersey. ${ }^{37}$ ECHO virus caused a small outbreak in Britain. ${ }^{38}$ Mumps, ECHO 2 and California encephalitis viruses were implicated as causes in one child. ${ }^{39}$ The question of anamnestic reaction arises. California arbovirus caused meningoencephalitis in sixty-six children in Minnesota between 1967 and 1972. All survived but $15 \%$ had sequelae. ${ }^{40}$ Type 1 poliomyelitis in eleven unvaccinated students in October 1972 in Connecticut emphasized the need for vaccination. ${ }^{41}$ Paralytic poliomyelitis type 3 developed after a month in an orally vaccinated person in 1963 . Ten years later in a suit against the U.S. government, $\$ 2$ million was awarded because of negligence in pretesting the vaccine for safety..$^{42}$

House sparrows and pigeons probably disseminated the St Louis encephalitis virus during an epidemic in Houston. ${ }^{43}$ Sparrows also harbour salmonellae. ${ }^{44}$
Rabies. Uncertainty persists about the value of vaccination. Although serious sequelae are rare, the low incidence of rabies in the U.S.A. makes the risk of reaction to the vaccine greater than the risk of rabies. Among 116 persons receiving duck-embryo vaccine, all had local reactions, $33 \%$ had constitutional symptoms and one had an anaphylactic reaction. ${ }^{45} \mathrm{~A}$ human cell culture of rabies vaccine evoked antibody without causing an untoward general reaction. ${ }^{46}$ Antiserum (Lederle Laboratory) is available commercially. ${ }^{47}$ It may interfere with active immunity induced by vaccine. ${ }^{48}$

A laboratory worker contracted the infection probably by inhaling aerosolized 'fixed' virus. ${ }^{49}$

\section{Viral respiratory tract infections}

Upper respiratory tract viral infections occur in the tropics in any season. In Bangkok, parainfluenza $(40 \%)$, respiratory syncytial $(13 \%)$ and adenoviruses $(13 \%)$ were the chief causes. A2 influenza appeared in August 1965 and dominated for 2 months. ${ }^{50}$ Elsewhere, viral infections, especially respiratory syncytial and parainfluenza 3, predominated as causes of pneumonia in infants. ${ }^{51}$ Viral infections often account for exacerbations of chronic bronchitis ${ }^{52}$ and do not require antimicrobial therapy.

Interferon applied intranasally prevented rhinoviral infection and viral shedding in inoculated volunteers. ${ }^{53}$ Inexplicably, vitamin $\mathrm{C}$ reduced the severity of colds in girls, but not in boys. ${ }^{54}$ Sceptical letters about its value appeared in Lancet of April 28 and in an editorial..$^{55}$ Both glyceryl guaiacolate and terpin hydrate are useless as expectorants. ${ }^{56}$ Large dosage of the latter injured the liver. ${ }^{57}$

Influenza affected three newborn infants. One had bilateral pneumonia on the first day of infection. ${ }^{58}$ Vaccination of patients who have a demyelinating disease is hazardous. ${ }^{59}$ A new vaccine (1972-73) effectively induced serum and nasal antibodies. ${ }^{60}$ Prophylaxis with amantadine seemed to prevent nosocomial infection ${ }^{61}$ but resistant strains of virus $A$ appeared in treated mice. ${ }^{62}$ The hope of averting pandemics rests on the improvement of vaccines as discussed in the June 8 and 15 issues of Science.

\section{Coxsackie virus}

An outbreak of Coxsackie virus B5 in a boys' summer camp probably had its source in lake water during bathing. Thirteen boys had pharyngitis. Conjunctivitis, pleurodynia, meningitis and dysentery occurred in one each. ${ }^{63}$ Evidence of Group B Coxsackie virus infection appeared in fifteen of twenty-one children with the haemolytic-uraemic syndrome, and the virus was recovered from two. ${ }^{64}$ Adenovirus type 2 caused haemorrhagic cystitis in seventeen children and three adults. ${ }^{65}$ As in the case of mumps, Coxsackie $B$ virus caused acute pancreatitis in two patients. ${ }^{66}$ 
Cytomegalovirus usually is invasive when hostresistance is impaired, but it caused nine cases of heterophil negative mononucleosis in otherwise healthy persons. Viruria was present in each. The infection is commoner than is generally believed. ${ }^{67}$ The virus was recovered from the cervix and demonstrated in human semen where it may remain for months without causing symptoms. ${ }^{68}$ Infection diagnosed by IgM antibody occurred in fourteen healthy adults and in sixteen with underlying disease. ${ }^{69}$

Viral dysentery caused two institutional outbreaks. Volunteers were infected by ingesting stool filtrates of patients. ${ }^{70}$ It probably is caused by an ether-stable, noncultivatable, $30 \mathrm{~nm}$-sized pox-like virus ${ }^{71}$ or a parvovirus. ${ }^{72}$ Intestinal biopsy of volunteers after ingesting the Norwalk agent showed minor villar changes and multivesiculate intracellular bodies. In the absence of inflammation, ${ }^{73}$ the term gastroenteritis is inappropriate.

Miscellaneous. Infectious mononucleosis continues to be misdiagnosed. Clinical, epidemiological, haematological and serological criteria for diagnosis must be observed before diagnosis is established. ${ }^{74}$ The transfer factor, probably the EB virus, persisted in the throat for months after the active infection. ${ }^{75}$ Cytarabine failed for treating varicella-zoster infection $^{76}$ and provoked adverse effects. ${ }^{77}$ ECHO 19 virus caused fatal hepatic necrosis in three neonates. ${ }^{78}$ According to Hammon, the cause of dengue haemorrhagic fever is uncertain. A viral mutation or selection, two viruses or other reasons may account for changes in its epidemiological and clinical characteristics. ${ }^{79}$ A nonfatal case of Lassa fever contracted in Africa was observed in London. ${ }^{80}$

Knowledge about drug therapy of viral infections was summarized. ${ }^{81}$ According to one opinion, there is no convincing evidence of the therapeutic value of pyrimidine, cytosine arabinose or purine nucleoside derivatives for varicella-zoster, herpes hominis encephalitis or cytomegalovirosis. $^{82}$

\section{Measles}

Fifty-one million doses of measles vaccine distributed after 1963, reduced the incidence of the disease from 480,000 to 75,000 in 1968 , deaths from 408 to 24 and encephalitis from 337 to 19 . The risk of vaccine encephalitis is $1: 1000 .^{83}$

Three articles in the May Journal of Pediatrics discuss the occasional failure of measles vaccination. Combined measles-mumps vaccine gave satisfactory antibody response in nearly all vaccinated children without significant side-effects. ${ }^{84}$ Bacteria seldom invaded the pneumonic lungs of African children. When they did, penicillin therapy aided in the severest cases, but prophylactic administration was deemed unnecessary.$^{85}$ Several instances of combined measles and varicella pneumonia are recorded. In an unusual fatal case in an infant, measles pneumonia appeared during varicella pneumonia. Interferon of the first infection probably failed to protect against the second. ${ }^{86}$

\section{Rubella}

Although vaccination seemed to end one epidemic ${ }^{87}$ routine vaccination of most children in a neighbourhood failed to prevent an outbreak of more than 1000 cases 9 months later ${ }^{88}$ Some victims of rubella spread the disease to many susceptible persons, others apparently infect only a few. Virus transmission is maintained in a population by spreader to spreader contact. Concurrent minor viral respiratory tract disease may increase dissemination of rubella.89 Pregnant women who are not serosusceptible should not be vaccinated. Vaccinated ones should receive contraceptive agents for three months. ${ }^{90}$

\section{Viruses and cancer}

By the age of $10,70-80 \%$ of persons in England had antibody against a 'new' polyoma virus. No illness occurred, but the agent may be oncogenic. ${ }^{91}$ Ten of seventy-four patients with functioning allografts excreted polyoma virus and inclusion-bearing cells in the urine. The prevalence of BK antibody was about the same as that found in the general population. ${ }^{22}$

Although evidence connecting EB virus with Burkitt's lymphoma 'is now almost complete', ${ }^{93}$ 'it is still premature to assume that EB virus causes Burkitt's tumour in any country . . ${ }^{94}$ Virus antibody during Burkitt's lymphoma in Africans and its absence in one-third of American patients suggests that different agents are causal or that the suspected virus is an unlikely cause. ${ }^{95}$

RNA virus particles were seen in, and cultured from, three renal cancers. Neutralizing antibody appeared in the blood. ${ }^{86}$ Malignant gliomas developed in hamsters inoculated with a papova virus from a patient with leukoencephalopathy. ${ }^{97}$ It still is uncertain if the supposed cancer viruses of man are causes or commensals. ${ }^{98}$ Hilleman summarized problems regarding interferons, vaccines and chemotherapy of viral diseases including cancer. The only effective vaccine for cancer in any species of animal is one for Marek's disease, a malignant neoplasm of chickens. ${ }^{99}$

\section{Bacillary infections}

An outbreak of diphtheria in the summer of 1970 in Texas involved nearly 200 patients, chiefly children, of whom two died, and 169 detected healthy carriers. Bacilli of the intermedius type dominated; 
mitis and gravis forms were less common. The types were not correlated with the severity of disease, nor were there differences in previously immunized or unimmunized patients. ${ }^{100}$

Multiple drug-resistant typhoid bacilli in the Mexican epidemic have spread elsewhere. Resistance also was transferred by the $\mathrm{R}$ factor to Esch. coli, and to other salmonellae. Cycloserine and gentamicin were antibacterial in vitro. ${ }^{101}$ In India ${ }^{102}$ and in Germany, ${ }^{103}$ trimethoprim-sulfamethoxazole was curative for typhoid. Relapses did not occur. The drug is useful for strains resistant to chloramphenicol or ampicillin. Actual invasion of Esch. coli from cheese, not absorption of toxin alone, caused dysentery in twenty-eight or thirty-seven persons. All recovered without antimicrobic therapy. ${ }^{104}$ Besides Esch. coli, Salmonella also may induce cholera-like stools, probably of toxic origin. ${ }^{105}$ Person-to-person spread of Yersinia enterocolitis affected six hospital employees. ${ }^{106}$ During 5 years, the incidence of ampicillin-resistant shigellae increased from none to $85 \%{ }^{107}$ Lomotil therapy for shigellosis prolonged the fever and caused other harmful effects. ${ }^{107 a}$

\section{Cholera}

Gastric hypochlorhydria increases the susceptibility to cholera, salmonellosis, and shigellosis, especially in poorly nourished populations. ${ }^{108}$ In 1892, Pettenkofer got cholera by ingesting vibrios after neutralizing his gastric juice with sodium bicarbonate. ${ }^{109}$ Two articles in the Lancet of June 2 concern the ineffectiveness of cholera vaccine. In 1972, forty cases occurred in Australia, two in Germany and in England. ${ }^{110}$ The occurrence of 150 cases and eighteen deaths in Naples in August 1973 induced much unnecessary preventive effort including vaccination. The ratio of overt to inapparent attacks was $1: 25$. A single case of unknown source occurred in Texas. A brief summary of new knowledge was published. ${ }^{111}$

Anaerobes, especially clostridia and cocci, appeared in blood cultures from 264 of 1307 patients with a death-rate of $31 \%{ }^{112}$ Bacteroides and streptococci caused $19 \%$ of empyemas in a 20 -year period with a death rate of $19 \%{ }^{113}$ Such infections are often overlooked because refined methods for identifying anaerobes seldom are applied. Ubiquitous saprophytic anaerobes may be colonizers or pathogens, usually in injured or degenerate tissues. Penicillin is the drug of choice for therapy and clindamycin for bacteroides. The matter is discussed in a monograph. ${ }^{114}$

\section{Miscellaneous bacillary infections}

In a 3-month period, thirty-nine persons in Utah contracted tularaemia chiefly from deerflies. A rabbit epizootic concurred. ${ }^{115}$ The first evidence of plague infection contracted from a carnivore occurred after skinning a bobcat in Arizona. ${ }^{116}$ Gram-negative bacilli caused osteomyelitis in sixteen patients or $28 \%$ of all cases. ${ }^{117}$ Minocycline apparently cured a dermal granuloma of 5 years' duration caused by Serratia. ${ }^{118}$ Antipertussis vaccine was not very effective in Britain where B. pertussis is the major cause of whooping cough. ${ }^{119}$ Vaccination to prevent pseudomonal infection in cancer patients had limited value and many untoward reactions ensued. ${ }^{120}$ Other Gram-negative bacillary infections are mentioned in the section on nosocomial disease.

BCG given to monkeys as an inhaled aerosol afforded greater protection against virulent $M$. tuberculosis than did parenteral injection. Inhaled aerosol vaccine induced weak dermal tuberculin reactivity. ${ }^{121}$ Forty-five infections with $\mathrm{Myco}$. intracellulare emphasized the importance of this disease and the need for aggressive therapy. ${ }^{122}$

Inapparent infections of leprosy occur as in almost all other infections. Among twenty-six persons living in an endemic area for 2 months, none responded to a test of immune response, but $24 \%$ of those exposed for a year responded and more than $50 \%$ in contact with victims did. ${ }^{123}$ Application of the transfer factor after chemotherapy apparently augmented the treatment of lepromatous leprosy. ${ }^{124}$ $M$. leprae multiplies in the foot-pads of mice, and widely scattered lepromas appeared in armadillos 15 months after inoculation. ${ }^{125}$ Trachoma, rampant in Asia and Africa and among Amerinds responded favourably to therapy with doxycycline for a total of 28 doses in 40 days. ${ }^{126}$ The causal microbe may be related to Gram-negative bacilli.

\section{Coccal infections}

\section{Pneumococcal infections}

Interest revived in the capsular swelling test. Few of the higher numbered types among the 82 types cause typical lobar pneumonia. They are invasive and cause 'atypical' pneumonia when host-resistance is low. ${ }^{127}$ More than 26 different pneumococcal serotypes, mostly of the higher numbered types, associated with 123 cases of pneumonia, make it unlikely that specific immunization will be practicable. ${ }^{128}$ The cocci can be typed directly in sputum within minutes and in an hour or two in peritoneal exudate after mouse inoculation without prior culture. Antimicrobials given before specimens are taken obscure diagnoses. Pneumococci were identified in $92 \%$ of previously untreated patients, but were absent in $69 \%$ of treated ones. ${ }^{129}$ Patients with sickle cell anaemia are subject to repeated attacks of pneumococcal pneumonia, often hard to distinguish from pulmonary infarction. ${ }^{130}$ Prior administration 
of tetracycline and chronic disease were factors in causing tetracycline-resistance of pneumococci in $5.7 \%$ of 400 patients. ${ }^{131}$ Blood-culture discovered bacteraemia in thirty-one of 708 ambulatory febrile children in a clinic, mostly with pneomococci and $H$. influenzae. ${ }^{132}$

Staphylococcus aureus, an omnipresent transient or persistent colonizer, rapidly becomes resistant to most antimicrobials. At times, it causes widespread epidemics especially as nosocomial infections in hospitals, and during influenza epidemics. ${ }^{133}$. In one patient it caused typical scarlet fever, vasculitis and fasciitis. ${ }^{134}$

Renal injury after Group A streptococcal infection is commoner than believed, but usually is asymptomatic. Among 248 infected children, fifty-four showed evidence of glomerulonephritis by biopsy. ${ }^{135}$ Nongroup A haemolytic streptococci, often of endogenous rather than of nosocomial origin, caused puerperal illness in most of seventy-three women. In three, scarlet fever, meningitis and pelvic abscess ensued. ${ }^{136}$

Paediatricians called attention to the importance of Group B streptococcal infections in infants in three papers in the April 1973 Journal of Pediatrics. Fortyfour infants had meningitis, others had septicemia or respiratory tract disease. The maternal vagina was the probable source. Allergic, clinical and immunological features of meningococcosis were described in two papers in the June 30 British Medical Journal.

\section{Gonorrhoea}

The incidence in the U.S.A. increased from 670,000 reported cases in 1971 to 758,000 in $1973^{137}$ and continues to increase. As a consequence the caserate of ophthalmia neonatorum has risen to 265/ $100,000 .{ }^{138}$ The cocci were in the pharynx of 150 patients, in $21 \%$ of homosexual men and $10 \%$ of women. Penicillin and tetracycline were effective in treatment, but spectomycin failed. ${ }^{139}$ Allergic reaction to penicillin followed in $0.66 \%$ of 27,673 patients. ${ }^{140}$

\section{Endocarditis}

The mortality rate from staphylococcal endocarditis remains about the same, $14 \%$ in patients less than 60 years old and in $71 \%$ of the rest. Classic signs often are absent. ${ }^{141}$ Staphylococcal and streptococcal infections developed in twenty-eight heroin addicts. ${ }^{142}$ Vancomycin-streptomycin was effective in treating enterococcal endocarditis. ${ }^{143}$ Whether 'synergism' is responsible is doubtful. Penicillingentamicin therapy cured four other patients with enterococcal endocarditis and two with meningitis. ${ }^{144}$ Seven endocardial infections with Lactobacillus plantarum are on record. One instance followed dental scraping. ${ }^{145}$ The mortality rate of Gramnegative anaerobic bacillary infection was $46 \%$. In one instance, 18 months of therapy with tetracyclineerythromycin failed, ${ }^{146}$ as one would expect. Fatal candida endocarditis and systemic involvement followed injury to the tricuspid valve by catheter insertion and multiple antimicrobial therapy. ${ }^{147}$

\section{Miscellaneous infections}

\section{Mycoplasmas}

Among sixty-two male college students with acute urethritis, gonococci probably were causal in only eight and T-strain mycoplasma in forty-six. Antimicrobial therapy cleared symptoms in the latter. ${ }^{148}$ Tetracycline had no obvious beneficial effect in five children with encephalitis and radiculitis. ${ }^{149}$ Genital mycoplasma salpingitis, post-partum fever and low birth-rate as a result of infection were reviewed. ${ }^{150}$ $\mathrm{T}$-strain mycoplasma was a colonizer more often in unmarried than in married women. ${ }^{151}$ It commonly was present in the genital tract of sexually active normal men probably as a commensal. ${ }^{152}$ The problem was discussed in the Journal of the American Medical Association of October 15, 1973. M. pneumoniae vaccine protected $87 \%$ of vaccines against infection and $66 \%$ against pneumonia. ${ }^{153}$

\section{Rickettsioses}

More than $98 \%$ of cases of tick typhus or tickborne pox (Rocky Mountain spotted fever) occur elsewhere than in the region named. In southeastern U.S.A., the incidence increased from 194 cases in 1959 to 432 in 1971. Antimicrobial treatment of vic. tims is easier to accomplish than the elimination of ticks. ${ }^{154}$ Colorado tick fever may be mistaken for tick typhus. ${ }^{155}$

\section{Mycoses}

Histoplasmosis in thirty-two children posed differential diagnostic problems. Fever, malaise, chest pain, and weight-loss occurred. Pneumonia was present in eleven, nineteen had lymphadenopathy and ten had hepato- or splenomegaly. ${ }^{156} \mathrm{~A}$ man had systemic disease and a penile lesion worsened by steroid therapy. He apparently transmitted the infection to his wife. ${ }^{157}$ Second attacks occurred in six persons, two with pulmonary infiltrates. As in tuberculosis, persons whose skin reacts to the dermal test are at risk. ${ }^{158}$ During 2 weeks, airborne dust from a bird roost, as on previous occasions, infected $40 \%$ of persons in a school. ${ }^{159}$

Inhaled contaminated cotton dust probably caused fatal Coccidioidomycosis in a mill worker in Georgia, a nonendemic region. ${ }^{163}$ Twenty-eight of eighty patients in whom Cryptococcus neoformans was present in sputum had pulmonary disease caused by that 
agent. The majority of patients recovered without antimicrobial therapy. ${ }^{161}$

\section{Others}

Entamoeba histolytica eats inflammatory cells as well as erythrocytes. Leukocytes therefore are not defensive against invasion. ${ }^{162}$ Therapy with combined emetine, chloroquine, metronidazole and tetracycline reduced the mortality rate of amoebic hepatic abscess to $2.3 \%$. Aspiration was needed only in $17 \%$ of 2322 patients. ${ }^{163}$

Despite chloroquine prophylaxis, six of eighty Danes who visited India had malaria 7-9 months later. ${ }^{164}$

The cat may be the definitive host of Toxoplasma gondii. Other small animals and birds are intermediate hosts. ${ }^{165}$ According to another view, ingestion of raw meat exceeded the importance of contact with animals, particularly cats, as a cause of toxoplasmosis, the cardinal evidence of which was lymphadenopathy. ${ }^{\mathbf{1 6 6}}$

New artificial lakes in Africa greatly increase the incidence of schistosomiasis by creating suitable milieus for snails. ${ }^{167}$ The discovery of salmonellae as parasites of schistosomes may account for the frequency of salmonellosis in patients with schistosomiasis. ${ }^{168}$ Cutaneous leishmaniasis appeared in ten marines who had served in Panama. ${ }^{169}$ Leptospirosis in 150 military personnel in South Vietnam exhibited fever alone. Without serological tests, forty-four cases would have been unrecognized as such. Mild cases are commoner than is generally believed. ${ }^{170}$

\section{Antimicrobial drugs}

According to the Director of the U.S. Food and Drug Administration, antimicrobial drugs, despite their great value, kill more than 30,000 persons a year. 'Over-the-counter' sales total about $\$ 1$ billion annually. ${ }^{171}$

As I continue to do, Kunin called attention to the over-use, especially of expensive drugs. In one hospital, therapy was not needed, or the choice of the drug was wrong, for $51.5 \%$ of patients, ${ }^{172}$ and in another report $60 \%$ of treated patients had no evidence of infection. ${ }^{171}$ Similar critique appeared elsewhere. ${ }^{173}$ In another study, no consistent logic appeared for ordering bacteriological studies, nor were their results heeded. Surprisingly, in one-third of cases, cultures were made while patients were receiving antimicrobials. ${ }^{174}$ About 2,400,000 kg (2640 tons) of antimicrobial drugs made in 1972 would suffice to treat two illnesses for every person in the U.S.A. Production of antimicrobials increased $320 \%$ and their cost $130 \%$ between 1960 and $1970 .{ }^{172}$

Large amounts in the blood of injected antimicrobials do not ensure sufficient amounts in infected tissues where they are needed. In interstitial spaces, the amounts are lower but persist longer. ${ }^{175}$ Intravenously injected antimicrobials, as with other substances, increased the amount of serum fibrinogen which may be mistaken for evidence of infection. ${ }^{176}$ Question concerns the value of topical application, especially of intrathecal injection for meningitis, and how much, if any, of the drug enters the meninges. Although injected drugs entered brain abscesses in effective amounts, disease persisted in six patients until pus was aspirated. ${ }^{177}$ Penicillin, penicillin/sulphasoxazole, erythromycin and ampicillin gave equally good results in treating acute otitis media in children. ${ }^{178}$

A guide for the use of antimicrobics for patients with impaired renal function was prepared. ${ }^{179}$ Large doses of penicillin may arrest marrow cells and cause pancytopenia. ${ }^{180}$ Among 13 brands of penicillins for oral application and 14 brands of ampicillin, inexpensive penicillin $\mathrm{V}$ is the drug of choice for treating non-serious Gram-positive coccal infections. ${ }^{181}$

Carbenicillin, an expensive penicillin that crossreacts with others, should be used only for treating pseudomonal, enterobacterial and indole-positive proteus infections so as to restrict the emergence of resistant strains. ${ }^{182}$ The same applies to clindamycin for anaerobic infections. ${ }^{183}$ Carbenicillino caused granulocytopenia in two patients. ${ }^{184}$ Clinda mycin, at present, is the drug of choice for treating bacteroides infection. ${ }^{185}$ In several instances, the drug has caused colitis ${ }^{186}$ and mucocutaneous fever. ${ }^{187}$ Its effect on acne is doubtful. ${ }^{188}$ Cephalexin probably will be of most value for treating urinary tract infections. ${ }^{189}$ Calf's liver contains an antimicrobial substance against Gram-negative bacilli. ${ }^{190}$

As usual many 'new' agents are available including Rosamycin, Cefoxitin, Vibramycin, Minocin, Cloxyquin, Cephacetrile, Cefazolin, Ticarcillin, Cotrimoxazole, Cuprimixin, and Isoconazole.

\section{Iatrogenic infections}

The increasing incidence of aspergillosis, toxoplasmosis and endocarditis during neoplastic diseases in relation to immunosuppressive therapy was discussed in several papers in the January 1973 American Journal of Medicine. Salmonella sepsis occurred in seven patients receiving immunosuppressive therapy. ${ }^{191}$ Several drugs induced hepatitis; methyldopa, for one, caused death according to two papers in the March issue of the Journal of Infectious Diseases. Osteomyelitis appeared in five patients receiving haemodialysis and corticosteroid therapy. ${ }^{192}$ Antimicrobial therapy rarely prevents or cures infection in immunologically suppressed patients. The drugs used were regarded as 'drugs of fear'. ${ }^{172}$ BCG therapy for cancer occasionally causes severe illness and tuberculous infection. ${ }^{193}$ 
Infections during other forms of therapy. Meningitis developed in five patients under treatment with cephalothin. ${ }^{194}$ Prior antimicrobial therapy was a factor in causing episodes of Gram-negative bacillary or mycotic pneumonias in sixty-eight leukaemic patients, and a death-rate of $65 \%{ }^{195}$ Similar circumstances pertained to seven cases of salmonella sepsis $^{191}$ after platelet transfusions. Cytomegalovirus infections and pneumonia followed marrow transplantation in twenty of fifty patients, with fourteen deaths. ${ }^{196}$ The incidence of hepatitis during isoniazid therapy was $1 \%$. Three of fourteen patients died. ${ }^{197}$ Antimicrobial prophylaxis not only failed to prevent postoperative wound infections but induced infections with drug-resistant bacteria. ${ }^{198}$

Mechanical factors. Transient bacteraemia with commensal bacteria followed nasotracheal intubation in $12 \%$ of children, and in $65 \%$ after exodontia. 199 Sigmoidoscopy induced similar bacteraemia in $9 \%$ of instrumented patients. ${ }^{200} \mathrm{~A}$ fatal case of clostridial sepsis followed a barium enema. ${ }^{201}$ Among 122 patients receiving nutrition parenterally, tube-tips harbouring Candida or staphylococci caused bacteraemia in five. Fourteen others had Gramnegative bacillary or enterococcal bacteraemia of other origin. ${ }^{202}$ Methods of control were outlined. ${ }^{203}$ Vials of multivirus vaccine probably contaminated with Myco. cheloni caused recurrent abscesses in forty-seven children. ${ }^{204}$

\section{Nosocomial infections}

Twenty-six cases of pseudomonal pneumonia in patients with serious underlying disease were hospital-acquired. Despite antimicrobic therapy, twenty-one died. ${ }^{205}$ In a review of 224 pneumonias, one-third were caused by Gram-negative bacilli, but specific causes could not be determined in $44 \%$. The death-rate was $50 \%$ with or without the administration of gentamicin. Disseminated mycotic superinfection followed in seventeen treated patients. ${ }^{206}$ Pseudomonal osteomyelitis and arthritis involved four of five patients, three of whom were receiving antimicrobics. ${ }^{207}$ Serratia caused destructive arthritis in three debilitated patients. ${ }^{208}$ Opportunistic streptococcal infections occurred in forty-four patients of whom twenty-four had neoplastic disease. ${ }^{209}$ Staphylococci caused endocarditis in twenty-eight heroin addicts, three with panophthalmitis, and five died. ${ }^{210}$ More than simple person-to-person spread accounts for nosocomial epidemics of salmonellosis. A hospital environment was extensively contaminated by eight infected patients, but others escaped infection. Spread occurs chiefly by contaminated food and drink. ${ }^{211}$ Within a day, ECHO virus infected four infants in an intensive-care unit. ${ }^{212} \mathrm{~A}$ patient with Lassa fever in a Liberian hospital spread the infection to three other patients and seven staff members of whom four died. Eight others probably were inapparently affected as described in two papers in the November American Journal of Tropical Medicine and Hygiene. The mode of contagion was undetermined. Knowledge of iatrogenic ${ }^{213}, 214$ and nosocomial $^{215}$ infections was summarized.

\section{Miscellaneous}

\section{Immunity}

Two articles and an editorial in the April 1973 Annals of Internal Medicine indicate that a defective cellular immune response may result from chemotactic dysfunction of monocytes. The immunoglobulins may be normal. Administration of a transfer factor may restore immune responsiveness in candidiasis. The transfer factor, a dialysable leucocytic extract, may soon be available for the treatment of infectious diseases when there is a defect in cellmediated immunity or anergy to one or more specific antigens. ${ }^{216}$ Knowledge of the transfer factor was summarized editorially in Lancet, ii, 79, 1973. The importance of immunoglobulins $A, D, E, G$ and $M$, and the differences between $B$ and $T$ lymphocytes involved in immune reactions were outlined. ${ }^{217}$ Marrow transplants may restore immunity. ${ }^{218}$ Deficient antibody, humoral and cellular activity are not alone responsible for poor defence against infections. A nurse with agammaglobulinaemia and lymphopenia had no infections for 14 years. Her serum had normal opsonizing ability. ${ }^{219}$

Follow-up study of seventy-four women entering hospitals for pyelonephritis between 1950 and 1960 disclosed repeated episodes within 3 years in twenty-nine $(40 \%)$ and within 6 months in sixteen $(23 \%)$. Hypertension affected ten, but most were in good health. ${ }^{220}$ Practical aspects of urinary tract infections were summarized. ${ }^{221}$

Among seventy military personnel in Vietnam with chronic and recurrent diarrhoea, Strongyloides or Giardia were present in twenty-five. Favourable responses to appropriate drugs occurred. ${ }^{222}$ Question often arises if Lamblia grow as commensals in abnormal tissue or are pathogenic.

Pets as sources of infection of man and diseases they transmit are listed respectively as follows: dogs or cats-visceral or cutaneous larva migrans, pasteurellosis, leptospirosis, cat-scratch fever, toxoplasmosis; birds-psittacosis, ptilosis; turtles and snakes-salmonellosis; monkeys-measles, arboviruses, amoebae and others; raccoons and dogsrabies. ${ }^{223}$

For diagnostic purpose, gallium-67 injected intravenously localizes in septic focal lesions in various areas detected by gamma camera scintiphotography. ${ }^{224}$

The American Type Culture Collection in Rockville, Md., preserves 16,000 strains of microbes for 
distribution to investigators. ${ }^{225}$ For longer, but nonviable preservation, precambrian rocks in the Grand Canyon contain fossilized spheroid and filamentous microbes. ${ }^{228}$

\section{References}

1. Bryan, J.A., Carr, H.E. \& Gregg, M.B. (1973) An outbreak of nonparenterally transmitted hepatitis B. Journal of the American Medical Association, 223, 279.

2. McCarty, D.J. \& Ormiste, V. (1973) Arthritis and HB Ag-positive hepatitis. Archives of Internal Medicine, 132, 264.

3. White, A.G. (1973) Medical disorders in drug addicts. Journal of the American Medical Association, 223, 1469.

4. Cherubin, C.E. \& Szmuness, W. (1973) The emerging epidemiology of hepatitis B antigen. Editorial, Annals of Internal Medicine, 79, 745.

5. DodD, R.Y. et al. (1973) Hepatitis B antigen: Regional variation in incidence and subtype ratio in the American Red Cross donor population. American Journal of Epidemiology, 97, 111.

6. Szmuness, W. et al. (1973) Hepatitis B antigen and antibody blood donors. Journal of Infectious Diseases, 127, 17.

7. Iwarson, S. et al. (1973) Subtypes of hepatitis B antigen in blood donors and post infectious hepatitis: Clinical and epidemiological aspects. British Medical Journal, $1,84$.

8. BARKer, L.F. et al. (1973) Antibody responses in viral hepatitis, type B. Journal of the American Medical Association, 223, 1005.

9. Journal of the American Medical Association (1973) Is fulminant viral hepatitis a systemic disease? Journal of the American Medical Association, 223, 1038.

10. Krugman. S. \& Giles, J.P. (1973) Viral hepatitis, type B (MS-2-strain). New England Journal of Medicine, 288, 755.

11. Melnick, J.L. (1973) A vaccine for viral hepatitis type B appears on the horizon. New England Journal of Medicine, 288, 790 .

12. HACKer, E.J. \& AACH, R.D. (1973) Detection of hepatitis-associated antigen and anti-HAA. Journal of the American Medical Association, 223, 414.

13. BARKer, L.F. et al. (1973) Transmission of Type B viral hepatitis to chimpanzees. Journal of Infectious Diseases, 127, 648 .

14. Provost, P.J. et al. (1973) Etiologic relationship of marmoset-propagated CR 326 hepatitis A rirus to hepatitis in man. Proceedings of the Society of Experimental Biology and Medicine, 142, 1257.

15. Mascoli, C.C. et al. (1973) Recovery of hepatitis agents in the marmoset from human cases occurring in Costa Rica. Proceedings of the Society of Experimental Biology and Medicine, 142, 276.

16. Holmes, A.W. et al. (1973) Specific neutralization of human hepatitis A in marmosets. Abstract, Program, American Society for Clinical Investigation, April, $\mathrm{p}$. 40a.

17. Feinstone, S.M., Kapikian, A.Z. \& Purcell, R.H. (1973) Hepatitis A: Detection by immune electron microscopy of a viruslike antigen associated with acute illness. Science, 182, 1026

18. Chang, T.-W., Fiumara, N. \& Weinstein, L. (1973) Herpetic chancre. Journal of the American Medical Association, 224, 129.

19. Florman, A.L. et al. (1973) Intrauterine infection with herpes simplex virus. Journal of the American Medical Association, 225, 129.

20. British Medical Journal (1973) Herpes hepatitis in adults. British Medical Journal, 1, 248.
21. Nolan, D.C., Lauter, C.B. \& Lerner, A.M. (1973) Idoxuridine in herpes simplex virus (Type 1) encephalitis. Annals of Internal Medicine, 78, 243.

22. SARUBBI, F.A. et al. (1973) Herpes hominis encephalitis. Archives of Neurology, 29, 268.

23. Felber, T.D. et al. (1973) Photodynamic inactivation of herpes simplex. Journal of the American Medical Association, 223, 289.

24. Journal of the American Medical Association (1974) Photoinactivation of herpesvirus may be clinically hazardous. Journal of the American Medical Association, 225, 459.

25. Journal of the American Medical Association (1974) BCG prevents recurrent herpes genitalis infection. Journal of the American Medical Association, 225, 466.

26. Nugent, G.R. \& CHOU, S.M. (1973) Treatment of labial herpes. Journal of the American Medical Association, 224, 132.

27. Science (1971) Cancer virus: Link to disease in man reported again. Science, 180, 572.

28. SPRECHER-Goldberger, S. et al. (1973) Increasing antibody titers to Herpes simplex virus type 2 during follow-up of women with cervical dysplasia. American Journal of Epidemiology, 97, 103.

29. Petersen, E.E. et al. (1972) Herpes simplex virus type 2: Its distribution and relationship to cervical carcinoma. Deutsche Medizinische Wochenschrift, 97, 1936.

30. Herpes Simplex, Varicella and Zoster. Clinical Manifestations and Treatment. (Ed. by B. E. Joel-Jensen and F. O. MacCallum.) J. B. Lippincott Co., Philadelphia, 1972.

31. Adams, J.M. et al. (1973) Vaccinia virus implicated in diffuse demyelinating disease. Proceedings of the $\vec{\theta}$ Society for Experimental Biology and Medicine, 143, 79श I

32. Brown, P., Cathala, F. \& Gajdusek, D.C. (1937 Further studies of viral antibodies in the cerebrospina fluid of patients with multiple sclerosis: Vaccinia and parainfluenza type 1. Proceedings of the Society for Experimental Biology and Medicine, 143, 828.

33. Barbosa, L.H. \& Hamilton, R. (1973) Virological studies with multiple-sclerosis brain tissues. Lancet, i, 1415.

34. JENIS, E. H. (1973) Subacute sclerosing panencephalitis. Archives of Pathology, 95, 81.

35. Baguley, D.M. \& Glasgow, G.L. (1973) Subacute sclerosing panencephalitis and Salk vaccine. Lancet, ii, 763.

36. Torrey, E.F. \& Peterson, M.R. (1973) Slow and latent viruses in schizophrenia. Lancet, ii, 22.

37. Goldfield, M. et al. (1973) A nonfatal human case of Powassan virus encephalitis. American Journal of Tropical Medicine and Hygiene, 22, 78.

38. Hart, R.J.C. \& Miller, D.L. (1973) Echovirus-17 infections in Britain, 1969-71. Lancet, ii, 661.

39. Balfour, H.H. et al. (1973) California arbovirus (La Crosse) infections. Pediatrics, 52, 680.

40. Balfour, H.H. et al. (1973) Meningoencephalitis and laboratory evidence of triple infection with California encephalitis virus, Echovirus II, and mumps. Pediatrics, $51,680$.

41. Weinstein, L. (1973) Poliomyelitis-a persistent problem. New England Journal of Medicine, 288, 370.

42. WADE, N. (1973) Division of Biologic Standards. Reaping the whirlwind. Science, 180, 162.

43. LORD, R.D. et al. (1973) Virological studies of avian hosts in the Houston epidemic of St. Louis encephalitis. American Journal of Tropical Medicine and Hygiene, 22, 662.

44. Quevado, F. et al. (1973) Isolation of Salmonella from sparrows captured in horse corrals. American Journal of Tropical Medicine and Hygiene, 22, 672. 
45. Rubin, R.H. et al. (1973) Adverse reactions to duck embryo rabies vaccine. Annals of Internal Medicine and Hygiene, 78, 643.

46. Wiktor, T.J., Plotkin, S.A. \& Grella, D.W. (1973) Human cell culture rabies vaccine. Journal of the American Medical Association, 224, 1170.

47. Annals of Internal Medicine (1973) Rabies antiserum availability. Annals of Internal Medicine, 78, 97.

48. Rubin, R.H., Sikes, R.K. \& Gregg, M.B. (1973) Human rabies immune globulin. Journal of the American Medical Association, 224, 871.

49. WinkLer, W.G. et al. (1973) Airborne rabies transmission in a laboratory worker. Journal of the American Medical Association, 226, 1219.

50. Olson, L.C. et al. (1973) The etiology of respiratory tract infection in a tropical country. American Journal of Epidemiology, 97, 34.

51. Zollar, L.M., Krause, H.E. \& Mufson, M.A. (1973) Microbiologic studies on young infants with lower respiratory tract disease. American Journal of Diseases of Children, 126, 56.

52. Lamy, M.E., Pouthier-Simon, F. \& DebackerWilliam, E. (1973) Respiratory viral infections in hospital patients with chronic bronchitis. Chest, 63 , 336.

53. Merrigan, T.C. et al. (1973) Inhibition of respiratory virus infection by locally applied interferon. Lancet, $\mathbf{i}$, 563.

54. Wilson, C.W.M. \& LoH, H.S. (1973) Common cold and vitamin C. Lancet, i, 638.

55. British Medical Journal (1973) Ascorbic acid and common colds. Editorial, British Medical Journal, 3, 311.

56. HirSCH, S.R., VierNes, P.F. \& KORY, R.C. (1973) The expectorant effect of glyceryl guaiacolate in patients with chronic bronchitis. Chest, 63, 9 .

57. Faierman, D. \& Jacobs, S. (1973) Liver injury from elixir of terpin hydrate with codeine. Mount Sinai Journal of Medicine, 40, 56.

58. Bauer, C.R. et al. (1973) Hong Kong influenza in a neonatal unit. Journal of the American Medical Association, 223, 1233.

59. RABIN, J. (1973) Hazard of influenza vaccine in neurologic patients. Journal of the American Medical Association, 225, 63.

60. Wenzel, R.P. et al. (1973) Revised (1972-1973) bivalent influenza vaccine. Journal of the American Medical Association, 226, 435.

61. O'Donoghue, J.M. et al. (1973) Prevention of nosocomial influenza infection with amantadine. American Journal of Epidemiology, 97, 276.

62. OXFORD, J.S. \& PotTer, C.W. (1973) Aminoadamantane-resistant strains of influenza A2 virus. Journal of Hygiene, 71, 227.

63, HaWley, H.B. et al. (1973) Coxsackievirus B epidemic at a boys' summer camp. Journal of the American Medical Association, 226, 33.

64. Austen, T.W. \& Ray, C.G. (1973) Coxsackie virus group B infections and hemolytic-uremic syndrome. Journal of Infectious Diseases, 127, 698.

65. NumAzaKi, Y. et al. (1973) Further study on acute hemorrhagic cystitis due to adenovirus type II. New England Journal of Medicine, 289, 344.

66. URSING, Bo. (1973) Acute pancreatitis in Coxsackie B infection. British Medical Journal, 3, 524.

67. Jordan, M.C. et al. (1973) Spontaneous cytomegalovirus mononucleosis. Annals of Internal Medicine, 79, 153. Editorial comment, 267.

68. Lang, D.J., Kummer, J.F. \& Hartley, D.P. (1973) Cytomegalovirus (CMV) in human semen. Abstract, Program, American Society for Clinical Investigation. April, p. 49a.
69. Sснмітz, H. (1973) Cytomegalovirus infection in adults. Deutsche Medizinische Wochenschrift, 98, 649.

70. BusCho, R.F. et al. (1973) Recurrent institutional outbreaks of acute infectious nonbacterial gastroenteritis: Epidemiology and etiology. American Journal of Epidemiology, 98, 192.

71. KAPICKIAN, A.Z. et al. (1973) Density in cesium chloride of $27 \mathrm{~nm}$ ' 8 FIIa' particles associated with acute infectious nonbacterial gastroenteritis. Proceedings of the Society for Experimental Biology and Medicine, $142,874$.

72. PAVER, W.K. et al. (1973) A small virus in human faeces. Lancet, i, 237.

73. Agus, S.G. et al. (1973) Acute infectious nonbacterial gastroenteritis: Intestinal histopathology. Annals of Internal Medicine, 79, 18.

74. DiRckX, J.H. (1973) Infectious mononucleosis. Journal of the American Medical Association, 226, 78.

75. Miller, G., Niederman, J.C. \& Andrews, L.L. (1973) Prolonged oropharyngeal excretion of Epstein-Barr virus after infectious mononucleosis. New England Journal of Medicine, 288, 229.

76. Davis, C.M., Van Dersarl, J.V. \& Coltman, C.A. (1973) Failure of cytarabine in varicella-zoster infections. Journal of the American Medical Association, 224, 122.

77. Stevens, D.A. et al. (1973) Adverse effect of cytosine arabinoside on disseminated zoster. New England Journal of Medicine, 289, 873.

78. Alistair. G.S., Philip, M.B. \& Larson, E.J. (1973) Overwhelming neonatal infection with ECHO 19 virus. Journal of Pediatrics, 82, 391.

79. Намmon, W.M. (1973) Dengue hemorrhagic fever-do we know its cause? American Journal of Tropical Medicine and Hygiene, 22, 83.

80. WoOdRufF, A.W. et al. (1973) Lassa fever in Britain. An imported case. British Medical Journal, 3, 616.

81. Weinstein, L. \& Chang, T.-W. (1973) The chemotherapy of viral infections. New England Journal of Medicine, 289, 725.

82. Karchmer, A.W. \& Hirsch, M.S. (1973) Cytosine arabinoside versus virus or man? Editorial. New England Journal of Medicine, 289, 912.

83. LANDRIgAN, P.J. \& WitTE, J.J. (1973) Neurologic disorders following live measles-virus vaccination. Journal of the American Medical Association, 223, 1459.

84. Weibel, R.E. et al. (1973) Combined live measlesmumps virus vaccine. Archives of Diseases in Childhood, 48, 532 .

85. O'Donovan, C. \& Barua, K.N. (1973) Measles pneumonia. American Journal of Tropical Medicine and Hygiene, 22, 73.

86. Lobes, L.A. \& Cherry, J.D. (1973) Fatal measles pneumonia in a child with chickenpox pneumonia. Journal of the American Medical Association, 223, 1143. Editorial, 1154.

87. Judelsohn, R.G. \& Wyll, S.A. (1973) Rubella in Bermuda. Journal of the American Medical Association, 223, 401 .

88. Klock, L.E. \& Rachelefsky, G.S. (1973) Failure of rubella herd immunity during an epidemic. New England Journal of Medicine, 288, 69.

89. Hatris, R.P. et al. (1973) Rubella in an immunized island population. Journal of the American Medical Association, 223, 1019.

90. Wyll, S.A. \& HerrmanN, K.L. (1973) Inadvertent rubella vaccination of pregnant women. Fetal risk in 215 cases. Journal of the American Medical Association, 225, 1472. 
91. Gardner, S.D. (1973) Prevalence in England of antibody to human polyomavirus (BK). British Medical Journal, 1, 77.

92. Coleman, D.V., Gardner, S.D. \& Field, A.M. (1973) Human polyomavirus infection in renal allograph recipients. British Medical Journal, 3, 371.

93. Epstein, M.A. \& ACHONG, B.G. (1973) Various forms of Epstein-Barr virus infection in man: Established facts and a general concept. Lancet, ii, 836.

94. Levine, P.H. \& O'ConNOR, G. (1973) E.B. virus and American and African Burkitt's lymphoma. Lancet, ii, 850.

95. Hirshaut, Y., Cohen, M.H. \& Stevens, D.A. (1973) Epstein-Barr-virus antibodies in American and African Burkitt's lymphoma. Lancet, ii, 114.

96. ElliotT, A.Y. et al. (1973) Isolation of RNA virus from papillary tumors of the human renal pelvis. Science, 179, 393.

97. WALKER, D.L. et al. (1973) Human papova virus (JC): induction of brain tumors in hamsters. Science, 181, 674

98. Journal of the American Medical Association (1973) RNA human cancer virus still eludes researchers. Medical News, Journal of the American Medical Association, 223, 731.

99. Hilleman, M.R. (1973) Perspectives in the control of viral diseases including cancer. In: Immunity in Viral and Rickettsial Diseases (Ed. by A. Kohn and M. A. Klingberg), pp. 167-178. Plenam Publishing Corp., N.Y.

100. Marcuse, E.K. \& Grand, M.G. (1973) Epidemiology of diphtheria in San Antonio, Texas, 1970. Journal of the American Medical Association, 224, 305.

101. Lawrence, R.M., Goldstein, E. \& Hoeprich, P.D. (1973) Typhoid fever caused by chloramphenicolresistant organisms. Journal of the American Medical Association, 224, 861.

102. Sardesai, H.V., Karandikar, R.S. \& Harshe, R.G. (1973) Comparative trial of co-trimoxazole and chloramphenicol in typhoid fever. British Medical Journal, 1,82 .

103. Dammermann, R. (1973) Treatment of enteric typhoid with trimethoprim-sulfamethoxazole. Deutsche Medizinische Wochenschrift, 98, 1251.

104. Tullock, E.F. et al. (1973) Invasive enteropathic Escherichia coli dysentery. An outbreak in 28 adults. Annals of Internal Medicine, 79, 13.

105. Axon, A.T.R. \& Poole, D. (1973) Salmonellosis presenting with cholera-like diarrhoea. Lancet, i, 745.

106. Toivanen, P. et al. (1973) Hospital outbreak of Yersinia enterocolitica infection. Lancet, $\mathbf{i}, 801$.

107. Torrence, M.B. et al. (1973) Ampicillin-resistant Shigella. Journal of the American Medical Association, 226, 1359.

107a. Du Pont, H. L. \& HoRnick, R. B. (1973) Adverse effect of Lomotil therapy in shigellosis. Journal of the American Medical Association, 226, 1525.

108. Gianella, R.A., Broitman, S.A. \& Zamchek, N. (1973) Influence of gastric acidity on bacterial and parasitic enteric infection. Annals of Internal Medicine 78, 271.

109. Howard-Jones, N. (1973) Gelsenkirchen typhoid epidemic of 1901, Robert Koch, and the dead hand of Max von Pettenkofer. British Medical Journal, 1, 103.

110. Journal of the American Medical Association (1973) Importation of cholera. Journal of the American Medical Association, 223, 339.

111. Adams, M.M.E. (1973) Cholera: New aids in treatment and prevention. Science, 179, 552.

112. WiLson, W.R. et al. (1973) Anaerobic bacteremia. Mayo Clinical Proceedings, 47, 639.

113. Sullivan, K.M. et al. (1973) Anaerobic empyema thoracis. Archives of Internal Medicine, 131, 521.
114. Finegold, S.M. et al. (1973) Scope Monograph on Anaerobic Infections. Upjohn Co. Kalamazoo, Mich., @ pp. 6-69.

115. Klock, L.E., Olsen, P.F. \& Fukushima, T. (1973) Tularemia epidemic associated with the deerfly. $\overrightarrow{0}$ Journal of the American Medical Association, 226, 149.

116. Poland, J.D., Barnes, A.M. \& Herman, J.J. (1973) Human bubonic plague from exposure to a naturally infected wild carnivore. American Journal of Epidemiology, 97, 332.

117. Meyers, B.R. et al. (1973) Clinical pattern of osteomyelitis due to Gram-negative bacteria. Archives of $\mathrm{C}$ Internal Medicine, 131, 228.

118. EPSTEIN, E. \& CARSON, T.E. (1973) Serratia granuloma. Journal of the American Medical Association, 223, 670 .

119. British Medical Journal (1973) Efficacy of whoopingcough vaccines used in the United Kingdom before 1968. British Medical Journal, 1, 259.

120. Young, L.S., Meyer, R.D. \& Armstrong, D. (1973) Pseudomonas aeruginosa vaccine in cancer patients. Annals of Internal Medicine, 79, 518.

121. BarClay, W.R. et al. (1973) Protection of monkeys against airborne tuberculosis by aerosol vaccination with Bacillus Calmette-Guerin. American Review of $\vec{A}$ Respiratory Diseases, 107, 351.

122. Yeager, H. \& Raleigh, J.W. (1973) Pulmonary diseases due to Mycobacterium intracellulare. American Review of Respiratory Diseases, 108, 547.

123. Godal, T. \& Negassi, K. (1973) Subclinical infection in leprosy. British Medical Journal, 3, 557.

124. Journal of the American Medical Association (1973) Transfer factor therapy aids leprosy patients. Medical News. Journal of the American Medical Association 224, 456.

125. BINFORD, C.H. (1973) Nine-banded armadillo cited experimental model for leprosy. Tropical Medicine Hygiene and News, 22, 3.

126. HaShiwara, I. et al. (1973) Doxycycline treatment of chronic trachoma. Journal of the American Medical Association, 224, 220.

127. Merrill, C.W. et al. (1973) Rapid identification of pneumococci. New England Journal of Medicine, 288, 510.

128. Page, M.I. \& LUNN, J.S. (1973) Pneumococcal serotypes associated with acute pneumonia. American Journal of Epidemiology, 98, 255.

129. Spencer, R.C. \& Philip, J.R. (1973) Effect of previous antimicrobial therapy on bacteriological findings in patients with primary pneumonia. Lancet, ii, 349 .

130. BarRett-Connor, E. (1973) Pneumonia and pulmonary infarction in sickle cell anemia. Journal of the American Medical Association, 224, 997.

131. Gopalakrishna, K.V. \& Lerner, P.I. (1973) Tetracycline-resistant pneumococci. American Review of Respiratory Diseases, 108, 1007.

132. McGowaN, J.E. (1973) Bacteremia in febrile children seen in a 'walk-in' pediatric clinic. New England Journal of Medicine, 288, 1309.

133. Finland, M. (1973) Epidemic character of staphylococcal infections. Modern Medicine, Jan. 22, 38.

134. McCloskey, R.V. (1973) Scarlet fever and necrotizing fasciitis caused by coagulase positive hemolytic Staphylococcus aureus, phage type 85. Annals of Internal Medicine, 78, 85.

135. SAGel, I. et al. (1973) Occurrence and nature of glomerular lesions after Group A streptococci infections in children. Annals of Internal Medicine, 79, 492.

136. White, C.A. \& KoonTz, F.F. (1973) $\beta$-hemolytic streptococcic infection in postpartum patients. Obstetrics and Gynecology, 41, 27.

137. Archives of Internal Medicine (1973) VD totals. Archives of Internal Medicine, 131, 172. 
138. Snow, R.J. \& Wilfert, C.M. (1973) Epidemic reappearance of gonococcal ophthalmia neonatorum. Pediatrics, 51, 110.

139. Wiesner, P.J. et al. (1973) Clinical spectrum of pharyngeal gonococcal infection. New England Journal of Medicine, 288, 181.

140. Rudolph, A.H. \& Price, E.V. (1973) Penicillin reactions among patients in venereal disease clinics. Journal of the American Medical Association, 223, 499.

141. Watanakunakorn, C., Tan, J.S. \& Phair, J.P. (1973) Some salient features of Staphylococcus aureus endocarditis. American Journal of Medicine, 54, 473.

142. Dryer, N.P. \& Fields, B.N. (1973) Heroin-associated infective endocarditis. Annals of Internal Medicine, 78, 699.

143. Westenfelder, G.O. et al. (1972) Vancomycinstreptomycin synergism in enterococcal endocarditis. Journal of the American Medical Association, 223, 37.

144. Weinstein, A.J. \& Moellering, R.C. (1973) Penicillin and gentamicin therapy for enterococcal infections. Journal of the American Medical Association, 223, 1030.

145. AXELROD, J. et al. (1973) Endocarditis caused by Lactobacillus plantarum. Annals of Internal Medicine. $78,33$.

146. NASTRo, L.J. \& Finegold, S.M. (1973) Endocarditis due to anaerobic Gram-negative bacilli. American Journal of Medicine, 54, 482.

147. Alderson, G.L. \& Bernhardt, H.E. (1973) Candida endocarditis of the tricuspid valve. Journal of the American Medical Association, 224, 517.

148. MCCheSNey, J.A. et al. (1973) Acute urethritis in male college students. Journal of the American Medical Association, 226, 37.

149. Lerer, R.J. \& Kalavsky, S.M. (1973) Central nervous system disease associated with Mycoplasma pneumoniae infection. Pediatrics, 52, 658.

150. McCormack, W.M. et al. (1973) The genital mycoplasmas. New England Journal of Medicine, 288, 78.

151. McCormack, W.M., Rosner, B. \& Lee, Y-H. (1973) Colonization with genital mycoplasmas in women. American Journal of Epidemiology, 97, 240.

152. McCormack, W.M., Lee, Y-H., \& ZINNER, S.H. (1973) Sexual experience and urethral colonization with genital mycoplasmas. Annals of Internal Medicine, 78, 696.

153. Mogabgab, W.J. (1973) Protective efficacy of killed Mycoplasma pneumoniae vaccine measured in largescale studies in a military population. American Review of Respiratory Diseases, 108, 899.

154. Hattwick, M.A.W. et al. (1973) Surveillance of Rocky Mountain spotted fever. Journal of the American Medical Association, 225, 1338.

155. Spruance, S.L. \& Bailey, A. (1973) Colorado tick fever. Archives of Internal Medicine, 131, 288.

156. Kakos, G.S. \& Kilman, J.W. (1973) Symptomatic histoplasmosis in children. Annals of Thoracic Surgery, 15,622 .

157. Sills, M., Schwartz, A. \& Weg, J.G. (1973) Conjugal histoplasmosis. Annals of Internal Medicine, 79, 221.

158. Powell, K.E. et al. (1973) Acute reinfection pulmonary histoplasmosis. American Review of Respiratory Diseases, 107, 374.

159. BRODSKY, A.L. et al. (1973) Outbreak of histoplasmosis associated with the 1970 Earth Day activities. American Journal of Medicine, 54, 333.

160. Gelbach, S.H., Hamilton, J.D. \& Conant, N.F. (1973) Coccidioidomycosis. An occupational disease in cotton mill workers. Archives of Internal Medicine, 131, 254.

161. Hammerman, K.G. et al. (1973) Pulmonary cryptococcosis: Clinical forms and treatment. American Review of Respiratory Diseases, 108, 1116.
162. Griffin, J.L. (1973) Human amebic dysentery. Electron microscopy of Entamoeba histolytica. American Journal of Tropical Medicine and Hygiene, 21, 895.

163. TsaI, S.H. (1973) Experiences in the therapy of amebic liver abscess on Taiwan. American Journal of Tropical Medicine and Hygiene, 22, 24.

164. Horstman, P. (1973) Delayed attacks of malaria in visitors to tropics. British Medical Journal, 3, 440.

165. WALlaCE, G.D. (1973) The role of the cat in the natural history of Toxoplasma gondii. American Journal of Tropical Medicine and Hygiene, 22, 313.

166. Braveny, I. et al. (1973) Studies on epidemiology of toxoplasmosis. Deutsche Medinische Wochenschrift, 98, 535.

167. British Medical Journal (1973) Menace of man-made lakes. British Medical Journal, 1, 62.

168. Young, S.W. \& FARID, Z. (1973) Bacterial parasitization of the parasite. Journal of the American Medical Association, 224, 1534.

169. Kern, F. \& Pederson, J.K. (1973) Leishmaniasis in the United States. Journal of the American Medical Association, 226, 872.

170. Berman, S.J. et al. (1973) Sporadic anicteric leptospirosis in South Vietnam. Annals of Internal Medicine, 79, 167.

171. The Review, Blue Cross, Feb. 1973, p. 3.

172. Kunin, C.M., Tupasi, T. \& Craig, W.A. (1973) Use of antibiotics. Annals of Internal Medicine, 79, 555. Editorial Note, Antibiotics under drug spotlight. Annals of Internal Medicine, 79, 600.

173. Kagan, B.M., Fannin, S.L. \& Bardie, F. (1973) Spotlight on antimicrobial agents-1973. Journal of the American Medical Association, 226, 306. Antibiotics. Editorial, Journal of the American Medical Association, 226, 350 .

174. EDWARDS, L.D. et al. (1973) Ordering pattern and utilization of bacteriologic culture reports. Archives of Internal Medicine, 132, 678.

175. Сhisholm, G.D. et al. (1973) Concentration of antibacterial agents in interstitial tissue fluid. British Medical Journal, 1, 569. Editorial, British Medical Journal, 1, 567.

176. Morrison, J.C. et al. (1973) Effects of antibiotics on serum fibrinogen levels. Obstetrics and Gynecology, 42, 80

177. Black, P. (1973) Penetration of brain abscess by systemically administered antibiotics. Journal of Neurosurgery, 38, 705.

178. BASs, J.W. et al. (1973) Antimicrobials in the treatment of acute otitis media. American Journal of Diseases of Children, 125, 397.

179. Bennett, W.M., Singer, I. \& Coggins, C.H. (1973) Guide to drug usage in adult patients with impaired renal function. Journal of the American Medical Association, 223, 991.

180. Joorabchi, B. \& Kohout, E. (1973) Apparent penicillin induced arrest of mature bone marrow elements. British Medical Journal, 2, 26.

181. The Medical Letter (1973) Oral penicillins. The Medical Letter, 15, 42.

182. The Medical Letter (1973) Oral carbenicillin. The Medical Letter, 15, 29.

183. The Medical Letter (1973) Clindamycin. The Medical Letter, 15, 25.

184. Reyes, M.P., Palutke, M. \& Lerner, A.M. (1973) Granulocytopenia associated with carbenicillin in two patients. American Journal of Medicine, 54, 413.

185. Haldane, E.V. \& van Rooyen, C.E. (1972) Treatment of severe Bacteroides infections. Canadian Medical Association Journal, 107, 1177. 
186. Cohen, L.E., McNeill, C.J. \& Wells, R.F. (1973) Clindamycin-associated colitis. Journal of the American Medical Association, 223, 1379.

187. Fulghum, D.D. \& Catano, P.M. (1973) StevensJohnson syndrome from clindamycin. Journal of the American Medical Association, 223, 318.

188. British Medical Journal (1973) Antibiotics in acne vulgaris. British Medical Journal, 1, 65.

189. FInland, M. (1973) Oral and parenteral cephalosporins: The place of cephalexin in antibacterial therapy. Editorial, $S$. Karger, 3, 1.

190. Kornguth, M.L. \& Kunin, C. (1973) Purification of antibacterial compounds from calf liver. Proceedings of the Society for Experimental Biology and Medicine, $142,1083$.

191. Rhame, F.S. et al. (1973) Salmonella septicemia from platelet transfusions. Annals of Internal Medicine, 78, 633.

192. LeONARD, A. et al. (1973) Osteomyelitis in hemodialysis patients. Annals of Internal Medicine, 78, 651.

193. Mansell, P.W.A. \& Krementz, E.T. (1973) Reactions to BCG (Letter). Journal of the American Medical Association, 226, 1570.

194. MANGI, R.J. et al. (1973) Development of meningitis during cephalothin therapy. Annals of Internal Medicine, 78, 347.

195. Sickles, E.A. et al. (1973) Pneumonia in acute leukemia. Annals of Internal Medicine, 79, 528.

196. NeImAN, P. et al. (1973) Interstitial pneumonia and cytomegalovirus infection as complications of human marrow transplantation. Transplantation, 15, 478.

197. MAdDREY, W.C. \& BoitnotT, J.K. (1973) Isoniazid hepatitis. Annals of Internal Medicine, 79, 1.

198. O'RIORDAN, C. et al. (1973) A prospective study of wound infections on an orthopedic service. Clinical Orthopedics, 87, 188.

199. BerRY, F.E. et al. (1973) Transient bacteremia during dental manipulation in children. Pediatrics, 51, 476.

200. Lefrock, J.L. et al. (1973) Transient bacteremia associated with sigmoidoscopy. New England Journal of Medicine, 289, 467.

201. Richman, L.S., Short, W.F. \& Cooper, W.M. (1973) Barium enema septicemia. Journal of the American Medical Association, 226, 62.

202. Dillon, J.D. et al. (1973) Septicemia and total parenteral nutrition. Journal of the American Medical Association, 223, 1341.

203. Goldman, D.A. \& MAKI, D.G. (1973) Infection control in total parenteral nutrition. Journal of the American Medical Association, 223, 1360.

204. Borghans, J.G.A. \& Stanford, J.L. (1973) Mycobacterium cheloni in abscesses after injection of diphtheria, tetanus, pertussis and polio vaccine. American Journal of Respiratory Diseases, 107, 1.

205. Pennington, J.E., Reynolds, H.Y. \& Carbone, P.P. (1973) Pseudomonas pneumonia. American Journal of Medicine, 55, 155.

206. GraYBILL, J.R. et al. (1973) Nosocomial pneumonia.
A continuing major problem. American Review of $\frac{\widehat{\Phi}}{\mathrm{Q}}$ Respiratory Diseases, 108, 1130.

207. Grieco, M.H. (1972) Pseudomonas arthritis and osteo- $\stackrel{C}{.}$ myelitis. Journal of Bone and Joint Surgery, 54A, 1633.

208. Ramsdell, C.M. \& NorThruP, J.D. (1973) Serratia ज़ arthritis: Report of three cases. Southern Medical $\bar{O}$ Journal, 66, 889.

209. HABLE, K.A. et al. (1973) Group A $\beta$-hemolytic streptococcemia: Bacteriologic and clinical study of 44 cases. $\frac{\Phi}{\partial}$ Mayo Clinic Proceedings, 48, 336.

210. DREYER, N.P. \& FieldS, B.N. (1973) Heroin-associated infective endocarditis. Annals of Internal Medicine, 78, $\infty$ 699.

211. MacGregor, R.R. \& Reinhart, J. (1973) Person-toperson spread of Salmonella: A problem in hospitals. Lancet, ii, 1001.

212. Cramblet, H.G. et al. (1973) Nosocomial infection with ECHO virus type 2 in handicapped and premature infants. Pediatrics, 51. 603.

213. Mulroy, R. (1973) Iatrogenic disease. British Medical ir Journal, 2, 407.

214. GSELL, O.(1972) 8. Arzneimittelschäden und Infektionskrankheiten (Referat). Verhandlungen Deutschen Gesellschaft Pathologie, 56, 88.

215. SмITH, J. (1973) Opportunistic infection. British o Medical Journal, 2, 107.

216. Journal of the American Medical Association (1973) A discovery whose time has come: transfer factor. Medical News. Journal of the American Medical Association, 224. 9.

217. Science (1973) Immunology: Two immune systems capture attention. Science, 180, 45.

218. Science (1973) Restoring immunity: Marrow tran plants may do it. Science, $180,168$.

219. Spitler, L.E., Levin, A.S. \& Fudenberg, H.H. (197æ Agammaglobulinemia, absent delayed sensitivity an lymphopenia without infections. American Journal of Medicine, 54, 371.

220. Parker, J. \& Kunin, C. (1973) Pyelonephritis in young women. A 10-to-20-year follow-up. Journal of the American Medical Association, 224, 585.

221. Fass, R.J., Klainer, A.S. \& Perkins, R.L. (1973) Urinary tract infection. Practical aspects of diagnosis and treatment. Journal of the American Medical Assocition, 225, 1509.

222. Butler, R. et al. (1973) Chronic and recurrent diarrhea in American Servicemen in Vietnam. Archives of Internal Medicine, 132, 373.

223. The Medical Letter (1973) Diseases from pets. The Medical Letter, 15, 73. Sick snakes infect man. Journal of the American Medical Association, 225, 1302.

224. LitTENBERG, R.L. et al. (1973) Gallium 67 for localization of septic lesions. Annals of Internal Medicine, 79, 403.

225. Biomedical News (1973) Vast deepfreeze stores multitude of microorganisms. Biomedical News, February, p. 11.

226. SCHOPE, J.W., Ford, T.D. \& BREED, W.J. (1973) Microorganisms from the late precambrian of the $\sigma$ Grand Canyon, Arizona. Science, 179, 1319. 